\title{
THE EFFECT OF PHENOLIC AND POLYPHENOLIC COMPOUNDS ON THE DEVELOPMENT OF DRUG RESISTANCE
}

\author{
Lucia Birošová, Mária Mikulášová, Magdaléna Chromá
}

\author{
Department of Biochemistry and Microbiology, Faculty of Food and Chemical Technology, Slovak University of Technology, \\ Bratislava, Slovakia \\ e-mail: lucia.birosova@stuba.sk
}

Received: June 10, 2005; Accepted: September 25, 2005

Key words: Antibiotic resistance/Ciprofloxacin/Gentamicin/Antimutagen

The effect of two phenolic compounds vanillin (4-hydroxy-3-methoxybenzaldehyde) and lignin on the development of drug/antibiotic resistance in Salmonella typhimurium was studied. Using the modified Ames test we have shown that vanillin alone has negligible effect on spontaneous mutability to ciprofloxacin and gentamicin resistance. At the tested concentrations vanillin reduces the toxicity of 4-nitroquinoline- $N$-oxide (4NQO) and reduces the ability of this compound to induce mutations leading to ciprofloxacin but not to gentamicin resistance. Lignin at higher concentrations increases mutagenicity to ciprofloxacin resistance and possess considerable inhibition effect on the spontaneous and 4NQO induced mutability to gentamicin resistance.

\section{INTRODUCTION}

The research of possibility how to reduce the frequency of both spontaneous and induced mutations in bacterial, somatic and germ cells is subject of interest for purely scientific reasons and for protection of human health. The occurrence of mutations is associated with fundamental life processes such aging, and variety of pathological conditions, including cancer and teratogenicity ${ }^{1}$.

Mutations are also the primary cause of drug/antibiotic resistance. Bacteria have evolved diverse mechanisms of resistance to antimicrobial agents, including alteration and protection of target sites, modification and detoxification of drugs and control of uptake and efflux of drugs. Recent approaches to solving problem of resistance include identification of new target sites and antimicrobial potentiation.

A new approach consists in the prevention of the development of mutations leading to antibiotic resistance using antimutagenic agents. Coumadin and related compounds could prevent the development of antibiotic resistance ${ }^{2}$. Sevag and Drable ${ }^{3}$ demonstrated that some polyamines (putrescine and spermidine) prevented development of resistance and Pillai et $\mathrm{al}^{4}$ showed that green tea catechins possess the potential to prevent or delay the development of resistance.

The purpose of this work was to examine the effect of two phenolic compounds vanillin and lignin on the mutagenesis leading to antibiotic resistance. Vanillin (4hydroxy-3-methoxybenzaldehyde) a naturally occurring compound in vanilla beans has been used widely as a flavouring agent in confectioneries, beverages and foodstuffs. It has been demonstrated that vanillin showed strong antimutagenic effects on mutagenesis of $4 \mathrm{NQO}$ and furylfuramide in Escherichia coli $^{5,6}$ and suppressing effects on chromosome aberration by mitomycin $\mathrm{C}$ in cultured Chinese hamster cells in vitro ${ }^{7}$. The addition of vanillin to 4NQO pre-treated cells led to an increased growth of $E$. coli cells accompanied with a fall of revertant colonies being induced by this mutagen ${ }^{8}$. Vanillin has protective effect on radiation-induced micronuclei and chromosomal aberrations in V79 cells ${ }^{9}$, can protect against photosensitization-induced ssbs in the plasmid pBR322 DNA, and this effect may partly be due to its ability to scavenge ${ }^{1} \mathrm{O}_{2}\left(\right.$ ref. $\left.^{10}\right)$. Shaughnessy et $\mathrm{al}^{11}$ confirmed that vanillin require SOS repair genes to produce an antimutagenic effect against spontaneous mutagenesis. On the contrary, vanillin showed comutagenic effects with $N$-methyl- $N$ '-nitro- $N$-nitrosoguanidine (MNNG) and $N$-methyl- $N$-nitrosourea (MNU) induced mutagenesis in E.coli WP2s (ref. ${ }^{12}$ ). Lignin is present in the cell walls of all plants, including edible plants and due to its antioxidant effects and high adsorption activity towards mutagenic compounds has antimutagenic and anticarcinogenic properties. In the microbial system of Salmonella typhimurium ligin reduced mutagenicity of 2-amino-3-methylimidazo [4,5-f]quinoline (IQ) (ref. $\left.{ }^{13}\right)$, 4NQO, 2-nitrofluorene and hydrogen peroxide ${ }^{14}$. Lignin inhibited the ability of 4NQO and hydrogen peroxide to induce the SOS response ${ }^{14}$ and reduced DNA strand breaks in $\mathrm{H}_{2} \mathrm{O}_{2}$ and MNNG treated mammalian cells ${ }^{15}$.

\section{MATERIAL AND METHODS}

Bacterial strain: Salmonella typhimurium TA 98 was received from the Collection of Microorganisms, Masaryk University, Brno (Czech Republic). 
Table 1. Effect of vanillin and lignin on the viability and on the spontaneous and 4NQO induced mutability to ciprofloxacin and gentamicin resistance

\begin{tabular}{|c|c|c|c|c|}
\hline \multirow{2}{*}{$\begin{array}{c}\text { Concentration } \\
\qquad \mu \mathrm{g} / \mathrm{ml}\end{array}$} & \multicolumn{2}{|c|}{ ciprofloxacin } & \multicolumn{2}{|c|}{ gentamicin } \\
\hline & \multirow{2}{*}{$\begin{array}{c}\begin{array}{c}\text { No. of cells } \\
\text { per culture }\end{array} \\
8.96 \times 10^{7}\end{array}$} & \multirow{2}{*}{$\begin{array}{c}\text { Frequency } \\
\text { of mutants }(\mathrm{RI})^{\mathrm{a}} \\
1.33 \times 10^{7}\end{array}$} & \multirow{2}{*}{$\begin{array}{c}\begin{array}{c}\text { No. of cells } \\
\text { per culture }\end{array} \\
7.40 \times 10^{7}\end{array}$} & \multirow{2}{*}{$\begin{array}{c}\text { Frequency } \\
\text { of mutants }(\mathrm{RI})^{\mathrm{a}} \\
2.73 \times 10^{6}\end{array}$} \\
\hline Vanillin & & & & \\
\hline 10 & $8.73 \times 10^{7}$ & $1.18 \times 10^{7}$ & $7.26 \times 10^{7}$ & $2.61 \times 10^{6}$ \\
\hline 50 & $8.46 \times 10^{7}$ & $1.44 \times 10^{7}$ & $7.04 \times 10^{7}$ & $2.51 \times 10^{6}$ \\
\hline 100 & $7.36 \times 10^{7}$ & $1.80 \times 10^{7}$ & $6.08 \times 10^{7}$ & $2.44 \times 10^{6}$ \\
\hline 500 & $7.26 \times 10^{7}$ & $1.96 \times 10^{7}$ & $5.89 \times 10^{7}$ & $1.92 \times 10^{6}$ \\
\hline \multirow[t]{5}{*}{ Lignin } & $7.43 \times 10^{7}$ & $1.12 \times 10^{7}$ & $6.56 \times 10^{7}$ & $2.84 \times 10^{6}$ \\
\hline & $6.99 \times 10^{7}$ & $0.94 \times 10^{7}$ & $6.03 \times 10^{7}$ & $1.50 \times 10^{6}$ \\
\hline & $6.56 \times 10^{7}$ & $0.62 \times 10^{7}$ & $5.79 \times 10^{7}$ & $0.81 \times 10^{6}$ \\
\hline & $4.74 \times 10^{7}$ & $1.82 \times 10^{7}$ & $4.16 \times 10^{7}$ & $0.83 \times 10^{6}$ \\
\hline & $2.69 \times 10^{7}$ & $3.00 \times 10^{7}$ & $2.51 \times 10^{7}$ & $0.84 \times 10^{6}$ \\
\hline \multirow[t]{4}{*}{$4 \mathrm{NQO}$} & $8.42 \times 10^{7}$ & $0.98 \times 10^{7}$ & $5.08 \times 10^{7}$ & $3.12 \times 10^{6}$ \\
\hline & $1.85 \times 10^{7}$ & $1.52 \times 10^{6}$ & $1.72 \times 10^{7}$ & $1.42 \times 10^{5}$ \\
\hline & $0.97 \times 10^{7}$ & $2.31 \times 10^{6}$ & $0.82 \times 10^{7}$ & $1.74 \times 10^{5}$ \\
\hline & $0.35 \times 10^{7}$ & $3.56 \times 10^{6}$ & $0.20 \times 10^{7}$ & $3.85 \times 10^{5}$ \\
\hline $4 \mathrm{NQO}^{\mathrm{b}}$ and vanillin 0 & $1.42 \times 10^{7}$ & $2.94 \times 10^{6}$ & $1.15 \times 10^{7}$ & $1.35 \times 10^{5}$ \\
\hline 10 & $5.91 \times 10^{7}$ & $1.92 \times 10^{6}$ & $4.92 \times 10^{7}$ & $1.37 \times 10^{5}$ \\
\hline 50 & $5.61 \times 10^{7}$ & $1.56 \times 10^{6}$ & $4.19 \times 10^{7}$ & $1.21 \times 10^{5}$ \\
\hline 100 & $5.14 \times 10^{7}$ & $1.35 \times 10^{6}$ & $3.92 \times 10^{7}$ & $1.05 \times 10^{5}$ \\
\hline 500 & $4.53 \times 10^{7}$ & $1.15 \times 10^{6}$ & $3.34 \times 10^{7}$ & $1.27 \times 10^{5}$ \\
\hline \multirow[t]{5}{*}{$4 \mathrm{NQO}^{\mathrm{b}}$ and lignin } & $2.05 \times 10^{7}$ & $3.11 \times 10^{6}$ & $1.85 \times 10^{7}$ & $1.28 \times 10^{5}$ \\
\hline & $5.57 \times 10^{7}$ & $2.10 \times 10^{6}$ & $4.12 \times 10^{7}$ & $0.64 \times 10^{5}$ \\
\hline & $4.27 \times 10^{7}$ & $0.50 \times 10^{6}$ & $3.79 \times 10^{7}$ & $0.47 \times 10^{5}$ \\
\hline & $3.81 \times 10^{7}$ & $1.32 \times 10^{6}$ & $3.36 \times 10^{7}$ & $0.42 \times 10^{5}$ \\
\hline & $2.48 \times 10^{7}$ & $1.51 \times 10^{6}$ & $2.19 \times 10^{7}$ & $0.37 \times 10^{5}$ \\
\hline
\end{tabular}

${ }^{a}$ The frequency of resistant mutants (resistance index RI) was expressed as the mean number of resistant colonies divided by the total number of viable cells per culture, ${ }^{b} 4 \mathrm{NQO}$ at concentration of $0.6 \mu \mathrm{g} / \mathrm{ml}$. The results are mean of the at least three experiments with five parallels.

Chemicals: 4-nitroquinoline- $N$-oxide (4NQO) and vanillin (4-hydroxy-3-methoxybenzaldehyde) were purchased from Sigma-Aldrich (Germany) and the sample of lignin was obtained from Department of Chemical Technology of Wood, Pulp and Paper, Faculty of Chemical and Food Technology, Slovak Technical University, Bratislava, Slovakia.

Ames test: The test was performed using the classical plate incorporation method according to Maron and Ames ${ }^{16}$.

Estimation of mutation frequency to antibiotic resistance: $0.1 \mathrm{ml}$ of overnight culture (cultivation for $16 \mathrm{~h}$ at $37^{\circ} \mathrm{C}$, approximate cell density $2-5 \times 10^{8}$ cells $\left./ \mathrm{ml}\right), 0.1 \mathrm{ml}$ of positive mutagen (4NQO), $0.1 \mathrm{ml}$ of tested antimutagenic compound and $0.5 \mathrm{ml}$ of phosphate buffer of $\mathrm{pH}$ 7.4 were mixed and preincubated at $37^{\circ} \mathrm{C}$ for $30 \mathrm{~min}$. In tests for spontaneous mutability the positive mutagen was omitted. Then $0.8 \mathrm{ml}$ of double strength nutrient broth was added and the cultures were incubated $3 \mathrm{~h}$ at $37^{\circ} \mathrm{C}$ to allow a few cell divisions and protein expression to occur. $2 \mathrm{ml}$ of melted top agar with an antibiotic were added and the mixture was poured on agar plates containing antibiotics at selective concentration $(2 \times \mathrm{MIC})$. After $72 \mathrm{~h}$ incubation at $37^{\circ} \mathrm{C}$ the number of resistant colonies was counted. The total number of viable cells was determined by plating an appropriate dilution of three cultures on nonselection medium. Plates were incubated aerobically for $24 \mathrm{~h}$ at $37^{\circ} \mathrm{C}$. The frequency of resistant mutants (resistance index RI) was expressed as the mean of resistant colonies divided by the total number of viable cells per culture. 
Statistical evaluation of results: Experiments were repeated independently at least three times in five parallel estimations and results were statistically evaluated using the Student's $t$-test.

\section{RESULTS AND DISCUSSION}

The frequency of mutation for ciprofloxacin and gentamicin resistance ranged from $9.5 \times 10^{-8}$ to $1.5 \times 10^{-7}$ and from $2.5 \times 10^{-6}$ to $3.3 \times 10^{-6}$, resp.

Vanillin alone doesn't possess a considerable effect on the mutability to ciprofloxacin or gentamicin resistance. As shown in Table 1, the resistance index of ciprofloxacin very slightly increased in the presence of vanillin and RI for gentamicin was slightly reduced (by about $30 \%$ ) at the highest used concentration of this phenolic compound.

4NQO induces the increase in the number of his + revertants in the Ames test (data not shown) and causes a considerable increase of mutation rate to antibiotic resistance. The effective concentrations of 4NQO are comparable in both types of mutations. 4NQO at concentration of $0.6 \mu \mathrm{g} / \mathrm{ml}$ causes an increase in the ciprofloxacin ( 23 fold) and gentamicin ( 6 fold) resistant index for Salmonella strain. We used this concentration of 4NQO in the antimutagenicity studies.

Vanillin considerably reduced the toxicity of 4NQO and reduced the frequency of mutations to ciprofloxacin resistance by $35 \%$ to $62 \%$, depending on the concentration. The ability of $4 \mathrm{NQO}$ to induce mutations to gentamicin resistance was reduced by vanillin very slightly.

Second phenolic compound tested for its possible preventive effect on the mutability for drug resistance - lignin, was more effective than vanillin.

$\mathrm{Up}$ to concentration of $50 \mu \mathrm{g} / \mathrm{ml}$ lignin was not toxic and reduced the number of spontaneous ciprofloxacin and gentamicin resistant mutants. At higher concentrations increased the mutation frequency to ciprofloxacin but not to gentamicin resistance.

The same course but with more considerable effect was noticed in the case of the influence of lignin on the 4NQO-induced mutagenicity. At the concentration of $50 \mu \mathrm{g} / \mathrm{ml}$ lignin reduced the RI induced by 4NQO by $83 \%$ and at higher concentrations this reduction was less substantial.

The addition of lignin reduced the 4NQO induced mutagenesis to gentamicin resistance and a clear doseresponse effect was notified. The resistance index was reduced to about $50 \%$ still at concentration of $10 \mu \mathrm{g} / \mathrm{ml}$ and the use of higher concentrations of lignin resulted in a further decrease in mutation frequency (Table 1).

\section{ACKNOWLEDGEMENT}

This work was supported by the Slovak Grant Agency VEGA (Project no. 1/1173/04)

\section{REFERENCES}

1. Shankel DM, Hartman PE, Kada T, Hollaender A. (1987) Synopsis of the First International Conference on antimutagenesis and anticarcinogenesis - mechanisms. Environ Mutagen 9, 87-103.

2. DeCourcy SJ, Barr MM, Blakemore WS, Mudd S. (1971) Prevention of antibiotic resistance in vitro in Staphylococcus aureus, Escherichia coli and pseudomonas aeruginosa by coumadin. $\mathrm{J}$ Infect Dis 123, 11-5.

3. Sevag MG, Drabble WT. (1962) Prevention of the emergence of drug-resistant bacteria by polyamines. Biochem Biophys Res Commun 8, 446-52.

4. Pillai SP, Pilai CA, Shankel DM, Mitscher LA. (2001) The ability of certain antimutagenic agents to prevent development of antibiotic resistance. Mutat Res 496, 61-73.

5. Ohta T, Watanabe M, Shirasu Y, Inouye T. (1988) Post-replication repair and recombination in $u v r A, u m u C$ strain of Escherichia coli and enhanced by vanillin, an antimutagenic compound. Mutation Res 201, 107-12.

6. Ohta T, Watanabe M, Watanabe K, Shirasu Y, Kato T. (1986) Inhibitory effects of flavouring on mutagenesis induced by flavourings in bacteria. Food Chem Toxicol 24, 51-68.

7. Tamai K, Tezuka H, Kuroda Y. (1992) Different modifications by vanillin in cytotoxicity and genetic changes induced by EMS and $\mathrm{H}_{2} \mathrm{O}_{2}$ in cultured Chinese hamster cells. Mutat Res 268, 231-37.

8. Mikulášová M, Bohovicová I. (2000) Genotoxic effect of vanillin derivatives. Biologia 55, 229-34.

9. Keshava C, Keshava N, Ong T, Nath J. (1998) Protective effect of vanillin on radiation-induced micronuclei and chromosomal aberrations in V79 cells. Mutat Res 397, 149-59.

10. Kumar SS, Ghosh A, Devasagayam TPA, Chauhan PS. (2000) Effect of vanillin on methylene blue plus light-induced single-strand breaks in plasmid pBR322 DNA. Mutat Res 469, 207-14.

11. Shaughnessy DT, Setzer RW, DeMarini DM. (2001) The antimutagenic effect of vanillin and cinnamaldehyde on spontaneous mutation in Salmonella TA104 is due to a reduction in mutations at GC but not AT sites. Mutat Res 480-481, 55-69.

12. Watanabe K, Ohta T, Shirasu Y. (1989) Enhancement and inhibition of mutation by $o$-vanillin in Escherichia coli. Mutat Res 218, 105-9.

13. Edenharder R, Leopold C, Kries M. (1995) Modifying actions of solvent extract from fruit and vegetable residues on 2-amino-3-methylimidazo[4,5-f] quinoline (IQ) and 2-amino-3,4dimethylimidazo[4,5-f]quinoxaline (MeIQx) induced mutagenesis in Salmonella typhimurium TA 98. Mutat Res 314, 303-18.

14. Mikulášová M, Košíková B. (2003) Modulation of mutagenicity of various mutagens by lignin derivatives. Mutat Res 535, 171-80.

15. Slameňová D, Horváthová E, Košíková B, Ružeková L, Lábaj J. (1999) Detection of lignin-biopolymer and vitamin E stimulated reduction of DNA strand breaks in $\mathrm{H}_{2} \mathrm{O}_{2}$ and MNNG treated mammalian cells by the comet assay. Nutr Cancer 33, 88-94.

16. Maron D, Ames B. (1983) Revised methods for the Salmonella mutagenicity test. Mutat Res 113, 173-215. 